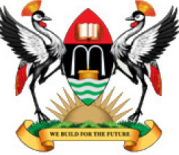

East African School of

Higher Education Studies \& Development
Makerere Journal of Higher Education

ISSN: $1816-6822 ; 3(1)(2011) 73-89$

DOI: http://dx.doi.org/10.4314/majohe.v3i1.7

(C) The Author(s) 2011

Reprints \& permission: EASHESD

http://ajol.info/majohe

\title{
Obstacles to the Internationalisation of Higher Education in Africa: the Case of Uganda
}

\author{
E. S. Kasenene ${ }^{1}$ \\ ${ }^{1}$ Makerere University College of Education [E-mail: kserugo@yahoo.co.uk]
}

\begin{abstract}
As the world turns into a global village, shifting from national to international higher education systems presents itself as a subject of critical concern. Thus, higher education systems and institutions are internationalizing their outlook and programs. However, in Africa, little has been published on the challenges these systems and institutions are experiencing in their efforts to internationalise their programs and outlook. Taking the case of Uganda, this study examines some of these challenges. Using a questionnaire adapted from related literature, data were elicited from 54 managers of HEIs in the country. The findings were that underfunding; inadequate government and donor support; staffing gaps; and administrative rigidity are constraining the internationalization of higher education in the country. Therefore, recommendations towards improving the institutions' funding, modes of delivery and collaboration with offshore HEIs are made.
\end{abstract}

Keywords: Internationalisation; Curriculum innovation; Cross border education

\section{$1 \quad$ Introduction}

The rate at which globalization is sweeping every part of the world is so fast that it is rendering advocates of the closed-economy-philosophy and its tenets obsolete every passing day. It is now rather utopian to think that a society can develop economically, technologically, socially, or educationally in isolation of others (Ahwireng-Obeng, 1999; Chakrabarti and Bhaumik, 2009; Sharma and Roy, 1996). Today's world trends demand an international outlook to every aspect of life, work and development, be it at individual, organizational or national level. Most of the human activities, jobs, workplaces, markets, services and facilities needed by a country and/ or its individual citizens to transform from one stage to another, have been globalized either in the manner of their production, procurement, delivery, or utilization (Reihlen and Apel, 2007). This 
has particularly been witnessed in the sectors of transport and communications, manufacturing, trade, hospitality, tourism, and most of all education generally and its higher education sub sector in particular (Hammond, 2009; Kathuria, Maheshkumar and Dellande, 2008; Mazzarol, Soutar and Sim Yaw Seng, 2003).

Globalization is not simply an advanced form of internationalization writ large. Unlike internationalization, globalization is at best indifferent to, and at worst positively hostile to, nation states. It celebrates the "low" world of mass consumerism, not the "higher worlds of diplomacy and culture and, as it is not tied to the past, is subversive of, and not supportive of, the established world order.

Intimately related to globalization is the growing recognition that national economic success can no longer be guaranteed solely by the mass production of consumer goods, or the physical exploitation of natural assets. Rather, it is becoming increasingly dependent on ability to create and use new ideas and knowledge. Globalization and the 'knowledge society' have also generated farreaching implications for higher education through the way in which they have transformed the nature of both our working lives and our daily lives. In today's education driven-economy, the message is loud and clear: if you don't learn, you won't earn.

Many institutions of higher learning, especially those in Europe, Asia and America have made tremendous efforts towards internationalization of their educational service delivery systems (Abdullahi, Kajberg and Virkus, 2007; Poh-Lin, 2004). They have initiated, promoted and continue to foster international cooperation, collaboration and networking not only amongst themselves but also between them and their counterparts in Africa (Ayoubi and Massoud, 2007; International Association of Universities (IAU), 2009). This has been taking place and continues to occur in form of redesigning of curriculum; fostering teamwork in the conduct and publication of higher education research and consultancies; conferencing; pursuing exchange training programmes; e-learning, promotion of desired quality assurance management; and supporting educational infrastructure development (Abdullahi and Kajberg, 2004; Hudson, 2003; IAU, 2009; Mihhailova, 2006). These institutions have been internationalizing their educational delivery systems for purposes of producing graduates who are not only competitive in the increasingly internationalizing job market but also compatibly relevant to the highly globalized development of their nations (Ahwireng-Obeng, 1999). They are also doing it as a means of promoting and maintaining their international competitiveness and buoyancy as centres of excellence in academics, cocurricular activities, instructional expertise, research and innovation (Reihlen and Apel, 2007; Monye, 1995). 
Unfortunately, the situation in Africa is rather different. The efforts made by African institutions of higher learning towards the internationalization of their educational service delivery systems have yielded little success (Knight, 2003). Indeed, African institutions of higher learning have been pursuing interuniversity collaboration in form of student exchange programmes, faculty or departmental cooperation, research, internet exchange of information and ideas, but they have not achieved the desired level of internationalization (IAU, 2007, 2009). Instead, they have benefited far less from the fostered collaboration than their overseas counterparts. This is particularly witnessed in Uganda.

While most of the foreign collaborating institutions of higher learning have largely computerized their educational service delivery and are subsequently finding it easy to access and exchange information, experience and ideas, their counterparts in Uganda are still grappling with poorly installed and inefficient internet systems as well as negligible levels of e-learning and internet supported distance education (Kayongo, 2009; Nabwire, 2008). As far as the pursued student and staff exchange programmes are concerned, Ugandan institutions of higher learning enrol far more foreign students and staff than they send to foreign collaborating institutions of higher learning. The influx of foreign students and academic staff into Ugandan institutions of higher learning may give an impression that Uganda's higher education is internationalizing. Whereas this impression may be true in terms of foreign student inflows, it is essentially illusory since it is not matched with an equivalent or greater outflow of Ugandan students and academic staff to foreign institutions of higher learning.

As a matter of fact, the Ministry of Education and Sports (2008) indicates that the number of foreign students enrolled by Ugandan institutions of higher learning is almost five times the number of Ugandan students admitted by the collaborating foreign institutions of higher learning. The same source shows that Ugandan institutions of higher learning receive more visiting professors and lecturers than they send to collaborating foreign institutions of higher learning. This indicates Ugandan institutions of higher learning receive less in terms of international mobility of students and staff than their counterparts. In the fostered international research and consultancy teamwork, foreign members of the constituted teams not only tend to dominate in number but are also paid almost thrice as much as their Ugandan counterparts. While Ugandan institutions of higher learning are declining as far as quality assurance management is concerned (Kayongo, 2008; Nabwire, 2008), the curve for their collaborating counterparts is steadily rising (IAU, 2009). The glaring economic and technological differences in favour of foreign countries suggest that graduates of collaborating foreign institutions of higher learning contribute more to the development of their and other nations than their Ugandan counterparts do to Uganda's and other countries' development. 
In general, the fore-described scenario indicates that compared to its counterparts in overseas countries, higher education in Uganda is far less internationalized in terms of quality, mobility of students and academic staff, benefits to Ugandans and global competitiveness. Why?

This article attempted to explore the reasons. It examined the challenges constraining the efforts of Ugandan institutions of higher learning to internationalize their educational service delivery systems to the level of their counterparts. The paper also attempted to come up with strategies by which the challenges can be overcome so as to promote the desired internationalization of higher education in Uganda. Accordingly, it endeavoured to answer the following questions:

1. What are the economic, political and curriculum challenges of internationalizing higher education in Uganda?

2. How can the challenges be addressed so as to promote the internationalization of higher education in Uganda?

\section{$2 \quad$ Methodology}

The methodology used to answer the foregoing questions involved reviewing literature on challenges of internationalizing higher education. It also involved administration of a questionnaire to 54 higher education officials and analysis of the collected data. The review of literature was intended to set a platform for exploring the obstacles to internationalizing higher education in Uganda. It therefore informed the designing of the questionnaire administered to the selected officials. The questionnaire was designed according to the themes derived directly from the foregoing questions.

University officials to whom the questionnaires were administered were selected from six institutions of higher learning (three private and three public institutions of higher learning). The institutions of higher learning were selected using simple random sampling so as to give each university an equal chance of being selected to take part in the study (Amin, 2005). A list of all private institutions of higher learning and another consisting of public institutions of higher learning of Uganda were compiled. Then three institutions of higher learning were selected from the public institutions of higher learning' list and three institutions of higher learning from the private institutions of higher learning' list without replacement. The selection of university officials followed thereafter.

University officials were selected using purposive sampling because only those who were considered as key informants were targeted. These included two top university administrators who included either the Vice Chancellor or 
University Secretary, depending on who of the two was available at the time of data collection, and a university's bursar. While any of the former two was selected to provide data on administrative challenges, the bursar was selected to provide data on financial challenges. Three faculty deans and four heads of departments were also selected to provide data on academic and non-academic challenges against internationalization of higher education. All the respondents were accessed in their respective offices. Attempts were made to first request for the willingness and cooperation of the selected officials before administering questionnaires to them. The request involved self-introduction and explaining the objective of the study. Any official who accepted to be a respondent was then given a questionnaire to fill in.

Data was analyzed using the mean comparison option of the descriptive method of the SPSS software, version 13. The challenges to internationalizing higher education in Uganda were identified using a five-point Likert scale of responses. The responses and their respective codes were; strongly disagree (1), disagree (2), not sure (3), agree (4) and strongly agree (5). All the questionnaire items were stated positively, implying that if a respondent agreed, then the item did not constitute an obstacle, more so if a respondent strongly agreed (Mean close to 5). If respondents disagreed (Mean close to 2), this meant that the embedded factor was a challenge, and a critical one if respondents strongly disagreed (Mean close to 1). Not sure (Mean close to 3) was considered as a neutral response pointing to respondents' uncertainty about whether a given factor was a challenge or not. The reviewed literature and findings obtained from the analysis are presented in the next sections according to the research questions.

\section{$3 \quad$ Related Literature and Findings}

The International Association of Universities (IAU) (2009) indicates that despite making appreciable efforts to initiate and foster alliances, cooperation, collaboration and networking, many African universities and institutions of higher learning have not reached the optimal level of internationalizing their education service delivery systems in many ways. They have made attempts to internationalize higher education in terms of inter-university cooperation and networking (IAU, 2008). This has largely been manifested in form of efforts to form and sponsor quality assurance practices (such as expansion of educational infrastructure, research supervision, vetting and examination), joint research teams and consultancies (Ahwireng-Obeng, 1999; IAU, 2007). Other efforts have been expressed in terms of forming and encouraging student and staff exchange programmes, competition in co-curricular activities, academic course 
diversification, and shifting from a term to a semester system (IAU, 2007). However, little success has been achieved due to a number of obstacles and challenges. These challenges are reviewed as presented in the next section.

\subsection{Obstacles to Internationalisation Higher Education}

Knight (2003) discussed some of the challenges as including: lack of policy or strategy to facilitate internationalization of higher education; lack of financial support; administrative inertia; lack of understanding of what is involved; insufficiently trained or qualified staff to guide the process; competing priorities; lack of reliable and comprehensive information; issues of nonrecognition abroad; and lack of opportunities.

A critical synthesis of these challenges reveals that higher education in Africa has failed to be internationalized mainly because of the internal management weaknesses of the continents' institutions of higher learning and factors characterizing their international operating environment. Indeed, the foregoing challenges show that African institutions of higher learning have not attained quality standards at which they can be recognized as internationally competitive institutions. The failure to attain such standards has also been highlighted in the work of Kasenene (2009), Kayongo (2008) and Nabwire (2008). Similar observations are made in the scholarly manuscripts of Malick and Grisay (2000), Munroe-Kavulya (2006), Munroe-Blum (2004), Tam WaiMing (2008), and Waithanji-Ngware and Ndirangu (2005).

Knight's (2003) highlighted challenges also indicate that African institutions of higher learning have not adequately marketed themselves in the international arena of higher education because they have not exploited the opportunities to do so. This is explained by the institutions' internal management weaknesses, which are revealed in Knight's (2003) observations as taking the form of organizational and administrative rigidities, inadequate knowledge of the internationalizing process, poor funding, and lack of necessary human resource and competences.

The available literature indicates that there is perhaps no challenge that has bedevilled the internationalization of higher education by African institutions of higher learning to the extent at which their funding has done so (Bitamazire, 2005; Getler and Glewwe, 1999; Glewwe and Jacoby, 1993; Jamil, 1992; Kajubi, 1992; Muyimbwa, 2004; Okoth-Ogola, 1995; Okwach, 2000; Saint, 1995; Ssekamwa, 1996; Tibarimbasa, 1989; Wamala, 2000; Woodhall, 1995). Poor funding explains why African universities have not adopted e-learning (Kayongo, 2009); yet this type of learning has been highlighted as one of the strategies for internationalizing higher education (Mihhailova, 2006). It is still a factor that has been cited as significantly critical in explaining the poor quality of educational services delivered by most of the African institutions (Munroe- 
Blum, 2004; Kayongo, 2008; Nabwire, 2008); thereby hindering them from attaining desired international competitiveness.

The local operating environment of African institutions of higher learning has also played a significant role in barring the institutions from achieving desired internationalization of their educational service delivery systems. According to Bray and Lillis (1988), majority of the students enrolled from local areas come from poverty-stricken backgrounds. They cannot raise the tuition needed by the institutions to attain even the minimum international educational excellence. On the contrary, students admitted from foreign countries find the tuition charged by these institutions affordable, even when their rates are in most cases higher than the locally charged rates (Makerere University, 2008). The fact that local students take precedence when admitting students to most African institutions of higher learning, especially those in the public domain implies, therefore, that the institutions have no choice but no provide educational services that the raised tuition fees can enable them to. The net effect of this is however to fail to achieve international competitiveness in terms of educational standards. No wonder that most of these institutions have to contend with lack of recognition in the international arena of higher education.

Another challenge has been cited as focusing on differences in educational systems and curricula in terms of content and programming. Most of the African institutions of higher learning follow either the British or French systems of education (Namutebi, 2008). This comes with its own barriers such as dissimilarities in the language of instruction, which complicate internationalization of higher education, especially in terms of student and staff exchange programmes. In fact, when students are exchanged, they waste a period of at least three months learning only the language of instruction. In addition, some African countries have tended to emphasize the fact that the curricula content of higher education should focus on developing and graduating students who can meet local development needs (Ministry of Education and Sports, 1989, 1992; Museveni, 1995). As a result, many institutions of higher learning are on the course of changing their curricula outlook so as to make it nationally oriented. Whereas this may be relevant in the short run, it may not be tenable in the long run, especially in view of the rapid globalization process. For it effectively limits internationalization of the education provided by the institutions.

Further, the system of instruction in most of the African institutions of higher learning is programmed in the manner that is inconsistent with the programming followed by similar institutions in overseas countries (IAU, 2005). While most of the African institutions of higher learning follow a termbased system curriculum programming and instruction (IAU, 2006), their counterparts in Europe and America follow a semester system (Abdullahi et al, 
2007; Ayoubi and Massoud, 2007). This complicates student exchange programmes since it effectively implies that students exchanged from one system to another have to lose time amounting to almost a whole academic before they are well incorporated.

In conclusion, it is important to note that while some of the fore cited observations were made in a manner that over-generalized all the institutions of higher learning in Africa, others were made focusing on institutions in South Africa, East Africa, West Africa or Kenya. Moreover, the geographical scope of some studies focuses on Europe or America. In addition, a critical synthesis of the context of the studies cited on Uganda's institutions reveals that they (the studies) were essentially not dealing with internationalization of higher education but rather other variables such as management, funding, and education systems, budget management, and so on. There was therefore a gap regarding whether the highlighted challenge also explain the low levels of internationalizing higher education in Uganda.

\subsection{Challenges of Internationalizing Higher Education in Uganda}

Accordingly, a questionnaire designed based on the foregoing literature was administered to the selected officials to gain an insight into the challenges of internationalizing higher education in Uganda. Indices were generated from Likert scale options that were coded as follows: $1=$ Strongly Disagree; $2=$ Disagree; $3=$ Not sure; $4=$ Agree; $5=$ Strongly Agree. For each item, the range of the response pattern was shown by the minimum and maximum values. The average response is shown by the mean value. The extent of dispersion from the average response pattern is shown by the standard deviation. A close scrutiny of the response pattern reveals that for two of the variables investigated (that is, "institution realizes all the funding needed to support internationalization of the education offered to students" and "Fees needed to internationalize education are affordable") the means were close to one and the magnitudes of the standard deviations were numerically very small, the inference being that all the respondents "strongly disagreed" with the items (Table 1). 
Table 1: Obstacles to Internationalisation of Higher Education in Uganda

\begin{tabular}{|c|c|c|c|c|}
\hline Attribute & Min & Max & Mean & $\begin{array}{l}\text { Standard } \\
\text { Deviation }\end{array}$ \\
\hline Institution has a policy for internationalizing programmes & 1 & 4 & 2.38 & 0.643 \\
\hline Curriculum mainly focuses on nationally-oriented education & 4 & 5 & 4.11 & 0.998 \\
\hline Institution's curriculum is internationally focused. & 1 & 5 & 3.63 & 0.505 \\
\hline Administration supports internationalisation of curricula & 1 & 5 & 3.54 & 0.504 \\
\hline $\begin{array}{l}\text { Managers are knowledgeable of what it takes to } \\
\text { internationalize education }\end{array}$ & 1 & 4 & 2.20 & 0.701 \\
\hline Academic staffs are qualified to internationalize education & 1 & 4 & 2.34 & 0.232 \\
\hline $\begin{array}{l}\text { Academic staffs propose programmes aimed at } \\
\text { internationalizing instruction offered }\end{array}$ & 1 & 2 & 2.04 & 0.070 \\
\hline Institution prioritizes internationalization of curricula & 2 & 5 & 3.90 & 0.201 \\
\hline Managers have information on the need to internationalize & 1 & 4 & 2.05 & 0.305 \\
\hline Institution is recognized internationally & 1 & 3 & 1.52 & 0.401 \\
\hline There are opportunities for internationalizing programmes & 1 & 4 & 1.57 & 0.905 \\
\hline Institution has the funds required for internationalization & 1 & 2 & 1.09 & 0.302 \\
\hline Institution has capacity to support internet-aided learning & 1 & 4 & 2.09 & 0.092 \\
\hline Fees needed to internationalize education are affordable & 1 & 2 & 1.14 & 0.070 \\
\hline Medium of instruction supports internationalization & 2 & 5 & 3.76 & 0.302 \\
\hline $\begin{array}{l}\text { Institution's calendar rhymes with calendars of other } \\
\text { countries }\end{array}$ & 2 & 4 & 1.90 & 0.201 \\
\hline
\end{tabular}

The mean responses imply that on average, respondents expressed strong dissent to the foregoing items. This implies that the factors that were embedded in these items were perceived as the most critical challenges to internationalization of higher education in Uganda. Disagreeing strongly to the items reveals that these challenges were:

1. Failure to realize all the funding needed to support internationalization of the education offered to students.

2. Inability of enrolled Ugandan students to pay the tuition and fees needed by the institutions to provide internationally competitive services. A further careful look at the results in Table 1 suggests that although the response range varied for the following items, the mean responses were close to ' 2 '.

3. The institution has a policy for internationalizing the education it provides to students.

4. The management of the institution is knowledgeable about what it takes to internationalize education offered to students.

5. The institution's academic staff members are sufficiently trained and qualified to guide internationalization of education offered to students.

6. The institution's academic year is well matched with the academic years of other institutions with which the institution exchanges students. 
7. The institution's bureaucracy does not frustrate efforts to internationalize offered education.

8. The management of the institution has information that keeps it reliably and adequately aware of what to do in order to internationalize the provided education.

9. The institution is at the desired level of recognition in the international arena of higher education.

10. Institution has opportunities to internationalize education

11. Institution receives all the funding needed to support internationalization of the education offered to students.

12. Institution has capacity to support internet-aided distance learning.

13. Institution's academic staffs design proposals for programmes aimed at internationalizing the education offered.

The findings imply that, on average, the respondents perceived the factors embedded in the foregoing items as challenges to internationalization of higher education in Uganda. "Disagreeing" to the items implies that Uganda's institutions of higher learning are still challenged by:

1. Lack of policy for internationalizing their education.

2. Their management not being adequately knowledgeable about what it takes to internationalize this education.

3. Their academic staff members being not adequately trained and qualified to guide internationalization of education offered to students.

4. Their academic years being not well matched with the academic years of other institutions outside Uganda.

5. Their frustrating bureaucratic administrative systems.

6. Their managements not lacking information needed to keep reliably aware of what to do in order to internationalize the education.

7. Their failure to attain the desired level of international recognition.

8. Having not opportunities to internationalize the provided education.

9. Lack of capacity to support internet-aided distance learning.

10.Failure of their academic staff members to design proposals for programmes aimed at making education offered to students internationally oriented.

On the contrary, the response range and mean responses in Table 1 reveal that the curriculum pursued by Uganda's institutions of higher learning was not a challenge to internationalizing the country's higher education. Despite the fact that it was largely nationally focused, it was perceivably not restricting the institution's efforts to internationalize this education. In addition all the institutions were also not challenged by lack of a charter to operate as nationally recognized institutions of higher learning. Important to note is that respondents were further asked to mention any other challenges that had not 
been highlighted in the pre-coded items. The thematic analysis of their responses revealed the following additional challenges:

1. Conservative attitude of top administrators.

2. Government delays in awarding of charters.

3. Institutional rivalry between the traditional institutions and newly established upcoming institutions (some institutions sabotage others through mudslinging).

4. Lack of donor support towards internationalized study programmes.

5. Differences in the structure of education and medium of instruction between countries in the region.

6. Political instabilities, which have affected the development of the higher education sector.

In general, results indicate that the internationalization of higher education in Uganda is still hampered by various challenges, the most critical of which are poor funding and inability of local students to pay the tuition fees that would enable the institutions of higher learning to build capacity that turn them into internationally competitive institutions.

\subsection{Strategies for Overcoming the Challenges to Internationalization of Higher Education}

A number of strategies have been highlighted, including integrating an international and intercultural dimension into the curriculum pursued by institutions of higher learning; promoting networking, cooperation, alliances, consortia; and adoption of internationalized academic and co-curricular disciplines, programs and content (IAU, 2007, 2008). Some of the programmes whose content can be internationalized are: Business Administration; Social Sciences; Health Sciences; Arts and Humanities; National Sciences; Engineering; and Information Technology (Chakrabarti and Bhaumik, 2009; Knight, 2003). Ahwireng-Obeng (1999) added Economics as another discipline that can be internationalized. Other cited strategies include: promoting online collaboration or adoption of e-learning as a means of supporting distance or online education; promotion of correspondence learning aided by post offices; encouraging student exchange programmes; and developing international teacher training and evaluation criteria (Ayoubi and Massoud, 2007; Hudson, 2003; Kayondo, 2009; Mihhailova, 2006; Monye, 1995; Poh-Lin, 2004; Waithanji-Ngware and Ndirangu, 2005).

Guided by the foregoing strategies, a number of questionnaire items were administered to the selected officials to establish the strategies that could be adopted to internationalize higher education in Uganda. The officials were asked to rank the given strategies according to how important the strategy was 
to internationalizing higher education. Results obtained from the indices analysis of their rankings are summarized in Table 2.

Table 2: Strategies for Overcoming the Obstacles to Internationalization

\begin{tabular}{lllll}
\hline & \multicolumn{2}{c}{ Min } & Max Mean & $\begin{array}{l}\text { Standard } \\
\text { Deviation }\end{array}$ \\
\hline Adoption of internationalized e-learning programmes & 1 & 3 & 1.11 & 0.101 \\
Adoption of internationalized learning experiences & 2 & 4 & 2.01 & 0.102 \\
Promoting inter-institutional cooperation in research & 3 & 5 & 3.31 & 0.111 \\
Encouraging student exchange programmes & 4 & 8 & 4.15 & 0.575 \\
Integrating an international dimension into curriculum & 5 & 9 & 5.21 & 0.207 \\
Supporting and participating in international symposia & 6 & 9 & 6.11 & 0.404 \\
Networking with overseas higher education institutions & 2 & 9 & 7.11 & 0.109 \\
Developing international teacher development criteria & 8 & 9 & 8.94 & 0.101 \\
Promotion of learning by correspondence & 7 & 9 & 8.78 & 0.876 \\
\hline
\end{tabular}

Results in Table 2 summarize the manner in which respondents ranked the strategies for overcoming the challenging to internationalization of Uganda's higher education. The standard deviations in Table 2 were all numerically small, suggesting low dispersion from the average ranking pattern. A close comparative scrutiny of the mean ranks reveals that the strategies were ranked with the first in the table as highest ranked and the last in the table as the lowest ranked strategy. Accordingly, adoption of online or e-learning as an internationalized programme was the highest ranked strategy $($ Mean $=1.11)$ followed by adoption of internationalized academic and co-curricular disciplines, programs and content (Mean $=2.01)$ and so forth.

Further attempt was made by asking selected respondents to outline any other strategies for overcoming the challenges of internationalizing higher education in Uganda. The thematic analysis of their responses indicated the following strategies:

1. Improving the funding of the institutions of higher learning through seeking donor support.

2. Alleviating poverty in Uganda by improving household incomes of the sponsors of higher education Ugandan students.

3. Building internal capacity in terms of in-service management training focused on equipping knowledge needed by institutional administrators to internationalize higher education.

4. Reducing the red tape against efforts to internationalize higher education. 


\section{Discussion, Conclusions and Recommendations}

Findings show that while a number of challenges are still bedevilling the internationalization of higher education in Uganda, those that are critical to this process are failure of the institutions of higher learning to realize all the necessary funding and the inability of enrolled Ugandan students to pay tuition and fees needed by the institutions to provide internationally competitive educational services. The findings are therefore consistent with the observations raised by Kayongo (2009), Getler and Glewwe (1999), Glewwe and Jacoby (1993), Jamil (1992), Kajubi (1992), Muyimbwa (2004), Okoth-Ogola (1995), Okwach (2000), Saint (1995), Ssekamwa (1996), Tibarimbasa (1989), Wamala (2000), and Woodhall (1995). Each of these scholars has shown that poor funding is a critical constraint to the ability of Uganda's institutions of higher learning to achieve desired and therefore internationally competitive educational excellence. Interestingly, the most critical challenges are related in such a way that one obstacle explains the other. Therefore, efforts to improve the funding of the institutions need to also consider how to improve the economic situation of the sponsors of the enrolled students.

Critical analysis of other challenges points to weaknesses in the institutions' internal management and organization of the institutions, inadequate government and donor support, unsupportive international and local operating environments, insufficient training of staff members and programming of academic years, which does not match with that of overseas institutions. The challenges are therefore consistent with those pointed out in the work of Knight (2003) and IAU (2005, 2006, 2007 and 2008).

In conclusion, the obstacles to against the internationalization of higher education in Uganda include: inadequate funding; inability of Ugandan students to pay tuition that the institutions need to internationalize competitively; inadequate government and donor support; insufficiency staff training, internal management and administrative weaknesses; unsupportive operating environment.

The strategies that institutions of higher learning in Uganda need to adopt in order to internationalize higher education include: improving their funding through seeking donor and government support; adopting online or e-learning, building internal capacity in terms of in-service management training; and encouraging government to enhance initiatives for poverty alleviation. Therefore, it is recommended that:

1. The government of Uganda should enhance initiatives for poverty alleviation as this will help improve the economic situation of sponsors of Ugandan students; thereby enabling them to pay tuition needed the 
institutions of higher learning to build internationally competitive educational capacity.

2. The government of Uganda should increase its funding to the higher institutions of learning.

3. Uganda's institutions of higher learning should put in more efforts to seek donor funding.

4. Uganda's institutions of higher learning should adopt online or e-learning as a means of internationalizing their education.

5. Administrators and managers of Uganda's institutions of higher learning should build internal capacity through in-service management training focused on equipping knowledge needed to internationalize higher education.

\section{References}

Abdullahi, I., Virkus, S. (2007). Internationalization of LIS Education in Europe and North America. New Library World 108, 200-217.

Abdullahi, I., Kajberg, L. (2004). A Study of International Issues in Library and Information Science Education: Survey of LIS Schools in Europe, the USA and Canada, New Library World 105, 220-234.

Ahwireng-Obeng, F. (1999). Internationalizing Economics Education in South Africa. Competitiveness Review: an International Business Journal Incorporating Journal of Global Competitiveness 1(9) 19 - 31.

Amin, M. (2005). Social Science Research: Conception, Methodology and Analysis. Kampala: Makerere University Printery.

Ayoubi, R. M., Massoud, H. K. (2007). The Strategy of Internationalization in Universities: A Quantitative Evaluation of the Intent and implementation in UK Universities. International Journal of Educational Management 4(21) 20-32.

Bray, M., Lillis, K. (Eds.) (1988). Community financing of education: Issues and policy implementation in LDCs. Oxford: Perganon.

Bitamazire, G. N. (2005). Ministerial Statement presented to Parliament by the Minister of Education. Kampala: MOES.

Chakrabarti, A., Bhaumik, P. K. (2009). Internationalization of Technology Development in India. Journal of Indian Business Research 1(1) 12-23.

Getler, P., Glewwe, P. (1999). Effects of Public Financing on Availability of education input resources in teacher training institutions in developing countries: evidence from Peru. Washington, DC: World Bank. 
Glewwe, P., Jacoby, H. (1993). 'Public financing of teacher education in lowincome countries: evidence from Ghana'. The Journal of Human Resources, 29 (3) 863-877.

Hammond, E. H. (2009). Internationalization in higher education and global access in a digital age, Library Management 30, 19-31.

Hudson, B. (2003). Promoting Collaboration in an international online learning community. Industrial and Commercial Training 3 (35) 13-25.

IAU (International Association of Universities) (2004). Examples of strategies for internationalization of higher education. Accessed on $12^{\text {th }}$ August 2009 at: http://www.unesco.org/iau/tfi_strategies.html.

IAU (2005). Towards a century of cooperation: internationalization of higher education, IAU statement. Accessed on $10^{\text {th }}$ August 2009 at: http://www.unesco.org/iau/tfi_statement.html.

IAU (2006). Internationalization of Higher Education. Accessed on $3^{\text {rd }}$ August at: http://www.unesco.org/iau/internationalization/letterEN.pdf.

IAU (2007). Internationalization of higher education: trends and developments since 1998. Accessed on $7^{\text {th }}$ August 2009 at: http://www.unesco.org/iau/internationalization/IAUrev.pdf.

IAU (2008). Internationalization of Higher Education, accessed on $3^{\text {rd }}$ August at: http://www.unesco.org/iau/internationalization.html.

IAU (2009). Internationalization of Higher Education. Accessed on $5^{\text {th }}$ August at: http://www.unesco.org/iau/internationalization/letterEN.pdf.

Jamil, S. (1992). Prospective on the financing of higher education. The Quarterly Journal of the International Association of Universities. 2(3) 5569.

Kajubi, S. W. (1992). Financing of Higher Education in Uganda. Kampala: Kluwer Academic Publishers.

Kasenene, E. S. (2009). Are African Universities Centres of Excellence? The consumer perspective of Ugandan universities, Makerere Journal of Higher Education, 2, 80-94.

Kathuria, R., Maheshkumar, P. J., Dellande, S. (2008). International growth strategies of service and manufacturing firms: the case of banking and chemical industries. International Journal of Operations and Production Management. 10 (28) 18-33.

Kayongo, P. (2009). Investing in the provision of e-learning services or establishing a physical higher educational institution: which way to go in financial terms? Journal of Bankers 2(4) 33-44.

Knight, J. (2003). Internationalization of higher education: practices and priorities. Quarterly Journal of International Association of Universities 1 (4), 33-47. 
Makerere University (2008). Speech of the Vice Chancellor delivered at the $34^{\text {th }}$ graduation ceremony at Makerere University Freedom Square. Makerere University: Unpublished.

Malick, L., Grisay, A. (2000). The quality of education in developing countries: a review of some case studies and policy documents. Paris: IIEP.

Mazzarol, T. Soutar, G. N., Sim Yaw Seng, M. (2003). The third wave: future trends in international education. International Journal of Educational Management 3(17) 13-25.

Mihhailova, G. (2006). E-learning as internationalization strategy in higher education: lecturer's and student's perspective. Baltic Journal of Management 3(1) 20-34.

Ministry of Education (1989). Education policy review commission's report. Kampala: Ministry of Education.

Ministry of Education (1992). Education for national integration and development: government white paper on the recommendations of the Education Policy Review Commission. Kampala: Ministry of Education.

Ministry of Education (2008). Report of Higher Education Review, 2001-2007. Kampala: MOES.

Monye, S. O. (1995). International marketing management: a separate academic discipline? An empirical assessment of the need for specialist education and training. International Marketing Review 3(12) 77-87.

Munroe-Kavulya, J. (2006). A survey of trends in funding of universities in Kenya. Journal of Higher Education Management 19(1) 22-30.

Munroe-Blum, H. (2004). Universities at crossroads: speech delivered to the Canadian Club of Montreal. Accessed on 25 ${ }^{\text {th }}$ February 2008 at: http://www.mcgill.ca/principal/speeches/crossroads/.

Museveni, Y. K. (1995). Some reminiscences of President Yoweri Museveni. Kampala: Recent Magazine.

Muyimbwa, P. (2004). The effects of liberalized funding on the management practices at Makerere University. Makerere University: Unpublished MA Ed Mgt Dissertation.

Nabwire, A. (2008). Budget management and quality of educational service delivery at Kyambogo University. Unpublished MBA dissertation: Makerere University.

Namutebi, E. (January, 2008). Comparison of the West and East African education systems. Paper presented to higher education students at the school of Education, Makerere University: Unpublished.

Okoth-Ogola, Y. (1995). The impact of financial constraints on the institutional management of higher education: the case of ITEK. Kampala: Makerere University, Unpublished M. Ed Dissertation. 
Okwach, S. (2000). Revitalising Financing of Higher education in Kenya: resource utilization in public in public universities. Social Sector Policy Review: Education. Number 1.

Poh-Lin, Y. (2004). International learning: antecedents and performance implications among newly internationalizing companies in an exporting context. International Marking Review 4(5) 21, 12-27.

Reihlen, M., Apel, B. A. (2007). Internationalization of Professional Service Firms as Learning: a Constructivist Approach. International Journal of Service Industry Management 2(18) 17-34.

Saint, W. S. (1995). Progress and potential for financial diversification in Universities in Africa. Higher Education Policy Journal 1 (8) 60-69.

Sharma, B., Roy, J. A. (1996). Aspects of the Internationalization of Management Education. Journal of Management Development 1(15) 96-113.

Ssekamwa, J. C. (1996). Financing education in Uganda: Past, Present and Future. Paper presented to M. Ed, MA Senior School of Education. $24^{\text {th }}$ March.

Tibarimbasa, A. K. (1989). The Financing of higher education: a case of Makerere University. Victoria University: Unpublished M. Ed Dissertation.

Tam Wai-Ming, F. (2008). The management of education quality: comparison of competing perspective. Accessed on $6^{\text {th }}$ March 2008 at: http://sunzil1.lib.hku.hk/hkjo/view/33/3300.

Waithanji-Ngware, M., Ndirangu, M. (2005). An improvement in instructional quality: can evaluation of teaching effectiveness make a difference? Quality Assurance in Education 3(13) 63-76.

Wamala, G. (2000). The perceptions of institutional administrators and lecturers on factors affecting staff development at Makerere University. Kampala: Unpublished M. Ed. Dissertation.

Woodhall, M. (1995). Financial diversification in higher education: a review of international experiences and implications for African universities. Higher Education Policy 1(18) 17-33. 